\section{Antibacterial activity of metabolites products of Vibrio alginolyticus isolated from sponge Haliclona sp. against Staphylococcus aureus}

\author{
Happy Nursyam \\ Faculty of Fisheries and Marine \\ Sciences, University of Brawijaya, \\ Malang, Indonesia
}

\begin{abstract}
The objective of this study was to investigate the antibacterial activity of primary and secondary metabolites from Vibrio alginoliticus isolated from sponge Haliclona sp. against Staphylococcus aureus. A descriptive method was used in this research. The antibacterial activity was analysed by paper disk method. The results showed that the primary metabolites produced by Vibrio alginoliticus that is in symbiosis with sponge Haliclona sp. were able to effectively inhibit Staphylococcus aureus growth with an inhibition zone diameter of $12.9 \mathrm{~mm}$, while the secondary metabolites of $9.9 \mathrm{~mm}$. Electrophoresis analysis of the primary metabolites showed that there were 11 protein bands which were not found in secondary metabolites. Protein bands with low molecular weights presumably had an inhibiting effect on the growth of Staphylococcus aureus.
\end{abstract}

\section{Introduction}

Indonesia is an archipelagic country whose natural resources have not been fully explored. The Indonesia natural resources, such plant, sponge, bacteria, etc. have been reported (Sabdono and Radjasa, 2006; Prihanto et al., 2012; Nursyam et al., 2013). The flora and fauna found in the ocean is a huge source for producing various bioactive compunds, i.e.: protein, omega-3, vitamins and hormones that are beneficial to health. Sponge is one of the marine organisms that are usually associated with microorganisms. These microorganisms are potential natural resources for the pharmaceutical industry (Mehbub et al., 2014). The sponge itself is the biggest source of bioactive compounds (Muniasih and Rachmawati, 1998). Therefore, bacteria or microorganisms that are associated with sponge more likely have bioactive compounds that are similar to the substrate that lives and breeds.

Sponge Haliclona sp. has antibacterial activity, antioxidant, anti-inflammatory and anticancer properties. Secondary metabolite from Haliclona sp. has been characterised by gas chromatography analysis. It was found that the active fraction on the basis of spectral data with GCMS is a fatty acid mixture. With this potency, we, therefore, need to exploit bioactives compound derived from marine bioresources (Bhimba et al., 2013)

The emergence of bacteria resistant to antibiotics is a big concern for exploring new antimicrobial agents (Nursyam et al., 2016). The trend of increasing resistance to antibiotics commonly used against $S$. aureus cannot be controlled until now and unless antibiotics are used more carefully (Akindolire et al., 2015). Most Staphylococcus aureus are being resistant to antibiotics. More than $30 \%$ of $S$. aureus is methicillin resistant. This causes a major risk for infection. This phenomenon resulted in a problem on the next selection of antimicrobial agents for the treatment of Staphylococci infection. Therefore, prudent antibiotic use and managing antibiotic with further research worldwide is necessary (Saha and Bal, 2013). Many report on bioactive compounds isolated from sponge. The main obstacle in the final development of it is sustainable supply. The concentration of highly active compounds from marine invertebrates is very small, so it is clear that we can not exploit a sponge for this purpose. Therefore, an alternative source for the supply of marine invertebrate organisms is indispensable. Furthermore, according to Suleria et al. (2015), almost all marine invertebrates are hosts for marine microorganisms such as bacteria, fungi and micro-algae. The symbiosis of microorganisms and marine invertebrates plays a role in the biosynthesis of bioactive compounds. According to Majali et al. (2015), contained metabolites in the sponge were strongly associated with invertebrates metabolites synthesized by microorganisms' simbion. One of the symbiont sponges is $V$. alginolitycus. The aim of this study is to determine the antibacterial activity of $V$. alginolitycus associated with sponge Haliclona sp. against $S$. aureus.

\section{Materials and Methods}

Haliclona sp. sample was collected at depths around one meter on January, 2016 at Gili Island-Probolinggo, East Java, Indonesia. The samples were placed on sterile bag and transferred to the laboratory as soon as possible. The samples were then stored at $4^{\circ} \mathrm{C}$ for the isolation of the microorganism for the next day.
Correspondence: Happy Nursyam, Faculty of Fisheries and Marine Sciences, University of Brawijaya, Jl. Veteran Malang 65145, Malang, Indonesia.

Tel: +62.341553512 - Fax: +62.341557837

E-mail: happy_nursyam@yahoo.com

Key words: Primary metabolite; Secondary metabolite; Antibacterial activity; Vibrio algonoliticus; Haliclona sp.

Conflict of interest: the author declares no potential conflict of interest.

Funding: the author would like to thank the rector of the UB-Indonesia, for funds that has been given to write the article.

Acknowledgements: the author is grateful to the all staff of Microbiology Laboratory of Faculty of Fisheries and Marine Science, University of Brawijaya, who helped the analysis.

Received for publication: 20 August 2016 Revision received: 21 November 2016.

Accepted for publication: 12 December 2016.

This work is licensed under a Creative Commons Attribution-NonCommercial 4.0 International License (CC BY-NC 4.0).

(C) Copyright H. Nursyam, 2017

Licensee PAGEPress, Italy

Italian Journal of Food Safety 2017; 6:6237

doi:10.4081/ijfs.2017.6237

\section{Isolation and identification of bacteria}

Isolation of Vibrio sp. from Haliclona sp. followed Gopi et al. (2012), with modification. The sponge was washed with tap water, $70 \%$ ethanol and sterile sea water. The sample was crushed and one gram of sample transferred to $9 \mathrm{~mL}$ solution of $0.9 \%$ Na-fisiologis. One $\mathrm{mL}$ of serially diluted samples were spreaded on selective media for Vibrio sp. namely, TCBS medium. After 24 hours incubation, appeared colonies were isolated.

Only the best candidate for antimicrobial compound was identified through morphological and biochemical test (Jahan et al., 2015). Furthermore, additional analysis by using Microbact system was applied. Microbact 24E (Oxoid, Basingstoke, UK) was used to identify the stain.

A total of five pure colonies of $V$. alginolitycus, which have been incorporated into TSA media, were centrifuged at 3000 rpm for 15 minutes. The pellets are added with Na-fis about $5 \mathrm{~mL}$ and then inserted into well in microbact $24 \mathrm{E}$ of $0.1 \mathrm{~mL}$ equal to $100 \mathrm{~mL}$ and incubated for $18-24$ hours at $30^{\circ} \mathrm{C}$. The colour change in the wells of microbact $24 \mathrm{E}$ was analysed by comparing 
the colour table and the result. Then the strain of the isolates could be determined.

\section{Antibacterial assay}

Two samples, namely metabolites primer and secunder were used. The bacteria were pre-cultured with only $5 \mathrm{~mL}$ on TSA medium. After 24 hour of the culture, the bacteria were transffered to $200 \mathrm{~mL}$ of the same media. Erlenmeyer flask was shakeed $250 \mathrm{rpm}$ and incubated on $30^{\circ} \mathrm{C}$.

For metabolite primer, the bacteria were harvested when the growth still in the first stage of log phase (after eight hour of main culture). The cells were separated by $10 \mathrm{~min}$ centrifugation for $7000 \mathrm{rpm}$ with $4^{\circ} \mathrm{C}$. Obtained cell were washed and sonicated for $10 \mathrm{~min}$ to extract the metabolite. After centrifugation with the same condition, supernatant was used for metabolite primer sample. For metabolite secunder, the bacteria was harvested when the bacteria reached nearly the end of log phase (after eighteen of main culture). The cells were separated by $10 \mathrm{~min}$ centrifugation for $7000 \mathrm{rpm}$ with $4^{\circ} \mathrm{C}$. Obtained supernatant was used for metabolite secunder sample. Density of the tested bacterium ( $S$. aureus) was $10^{8}$ $\mathrm{CFU} / \mathrm{mL}$, which was applied for antibacterial assay. Paper discs were soaked with metabolites and placed onto TSA plate. It was incubated at $37^{\circ} \mathrm{C}$ for 24 hours. Furthermore, diameter of formed clear zone was measured.

\section{Electrophoresis analysis}

Sodium dodecyl sulphate-polyacrylamide gel electrophoresis (SDS PAGE) analysis followed Laemmli (1970) method. Resolved protein visualized by silver staining. To determine the molecular weight of protein samples that have been tested done by calculating the retardaction factor (Rf) value of each bands. Molecular weight was calculated based on Rf value.

\section{Results and Discussion}

\section{Isolation and identification of bacte- ria}

Thiosulfate Citrate Bile Salts Sucrose (TCBS) medium will select only deduced vibrio species. Hence, it is a selective medium for $V$. alginolyticus. The results of bacterial cultivation on selective media were shown in Figure 1.

It is well known that Vibrio sp. is fluorescent or yellow when grown on TCBS. It is because sucrose in the media is fermented. In addition, positive oxidase of $V$. alginoliticus marked by the purple colour has not changed (Mustapha et al., 2012). Before characterization of the isolate, five pure colonies checked for their antibacterial acti- vity against $S$. aureus. From this result (unpublished data), the best colony in regard of their inhibition, is further investigated.

The results of biochemical test by using manual and microbact system suggested that the isolate was $V$. alginolitycus. shown on the percentage rate of $98 \%$. Identification of $V$. alginolitycus by manual and microbact method could be seen in Table 1. The colour change result on Microbact E-24 system was shown in Figure 2 and described in Table 2.

$V$. alginolitycus is a type of bacteria that live on a relatively high salinity. Most fluorescent bacteria are halophilic and optimally growth at 20-40\% salinity of seawater. Vibrio alginolyticus that has been identified

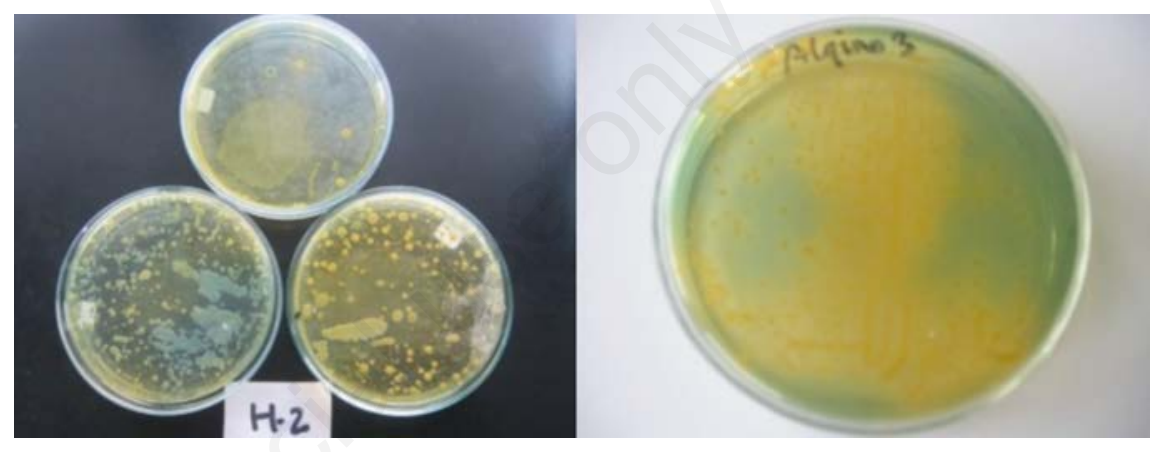

Figure 1. The growth of bacteria on Thiosulfate Citrate Bile Salts Sucrose medium. A) Vibrio sp. isolated from Haliclona sp.; B) pure isolates of Vibrio sp.

Table 1. Identification results of Vibrio alginolyticus isolated from Haliclona sp.

\begin{tabular}{lcc} 
Types of tests & Methods & Results \\
Morphological & Naked eye investigation of colony & Circular with regular, edges, slightly convex \\
Microscopical & Gram staining & Gram negatif \\
\hline Physiological & Catalase; oxidase; microbact system &,,$++ 98 \%$ of Vibrio algynoliticus \\
\hline
\end{tabular}

Table 2. Results of Microbact E-24 analysis of Vibrio alginolitycus.

\begin{tabular}{lccc} 
Biochemical test & Result & Biochemical test & Result \\
Lysine & + & Gelatin & + \\
Ornithige & + & Mallonate & - \\
\hline $\mathrm{H}_{2} \mathrm{~S}$ & - & Inositol & - \\
Glucose & + & Rhamnose & + \\
Mannitol & - & Sucrose & - \\
Xylose & + & Lactose & - \\
ONPG & + & Arabinose & - \\
Indole & - & Adonnitol & - \\
\hline Urease & - & Rafinose & - \\
VP & + & Salicin & - \\
\hline Citrate & - & Arginin $24 \mathrm{~h}$ & - \\
TDA & - & Arginin $48 \mathrm{~h}$ & - \\
\hline
\end{tabular}

ONPG, o-nitrophenyl- $\beta$-D-galactoside; VP, Voges-Proskauer; TDA, tryptophan deaminase.

is yellow and has a diameter of 3-5 $\mathrm{mm} . V$. inolitycus is a gram-negative, fermentaduction, and positive glucose. Vibrio sp. yellow/fluoresces on TCBS media for fermenting sucrose were contained in the edium (Costinar et al., 2010).

The observations were conducted after -24 hour incubation. Observation of the phase of $V$. alginolitycus bacterial phase in order to determine harvest time of bacteria. It is important to achieve primary bacteria was shown in Figure 3.

Primary metabolites extracted from the bacteria is on the stationary phase (Figure 2). In this phase has been known that bacte-

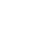


ria are in the maximum amount, which is about $28 \times 10^{8} \mathrm{CFU} / \mathrm{mL}$ at the $19^{\text {th }}$ hours. The speed of growth and proliferation is zero, this is due to environmental conditions have changed and are not beneficial to the growth and proliferation of battery. Zhang et al. (2015), state the condition is caused by exhaustion of nutrients as well as the buildup of toxic metabolic outcomes. The number of newly formed cell is balanced by the number of cells that die.

Secondary metabolites are taken on a decline phase because in this phase there is an increase in bacterial cell deaths that affect the population. This is due to the reduction of nutrients and metabolic waste accumulated more bacterial cell growth is allowed to live in metabolic waste material from dead cells. Secondary metabolites released by bacteria in self-defense (Hassan et al., 2015). From the observation was shown that the decline phase starts at the $20^{\text {th }}$ hour with an average of $2.7 \times 10^{8}$ $\mathrm{CFU} / \mathrm{mL}$

\section{Antibacterial activity of Vibrio algi- nolyticus}

The observation of the antibacterial activity of primary and secondary metabolites of $V$. alginolitycus symbiont Haliclona sp. is shown in Figure 4.

The existence of a clear zone around the paper disc indicated that the extract had an antibacterial activity. Clear zone were only found in metabolite primer extract. Zone of inhibition of primary metabolites are $12.99 \pm 0.82$. This indicates that the primary metabolite $V$. alginolitycus was more useful for anti $S$. aureus.

Secondary metabolites of $V$. alginolitycus are less effective for inhibiting the growth of $S$. aureus. The diameter of inhibi- tion zone of secondary metabolites of the bacteria $V$. alginolitycus against $S$. aureus was neglectable (Sugito et al., 1997). Aydin et al. (2011), states that the primary metabolites of $V$. alginolitycus have a greater inhibitory zone against the target bacteria than secondary metabolites.

\section{Electrophoresis}

To compare the protein which contained in metabolite primer and secunder, the electrophoresis analysis was conducted. The results of SDS-PAGE of the primary and secondary metabolites produced by $V$. alginolitycus symbiont with the sponge Haliclona sp. was depicted in Figure 5, while the calculation results are shown in

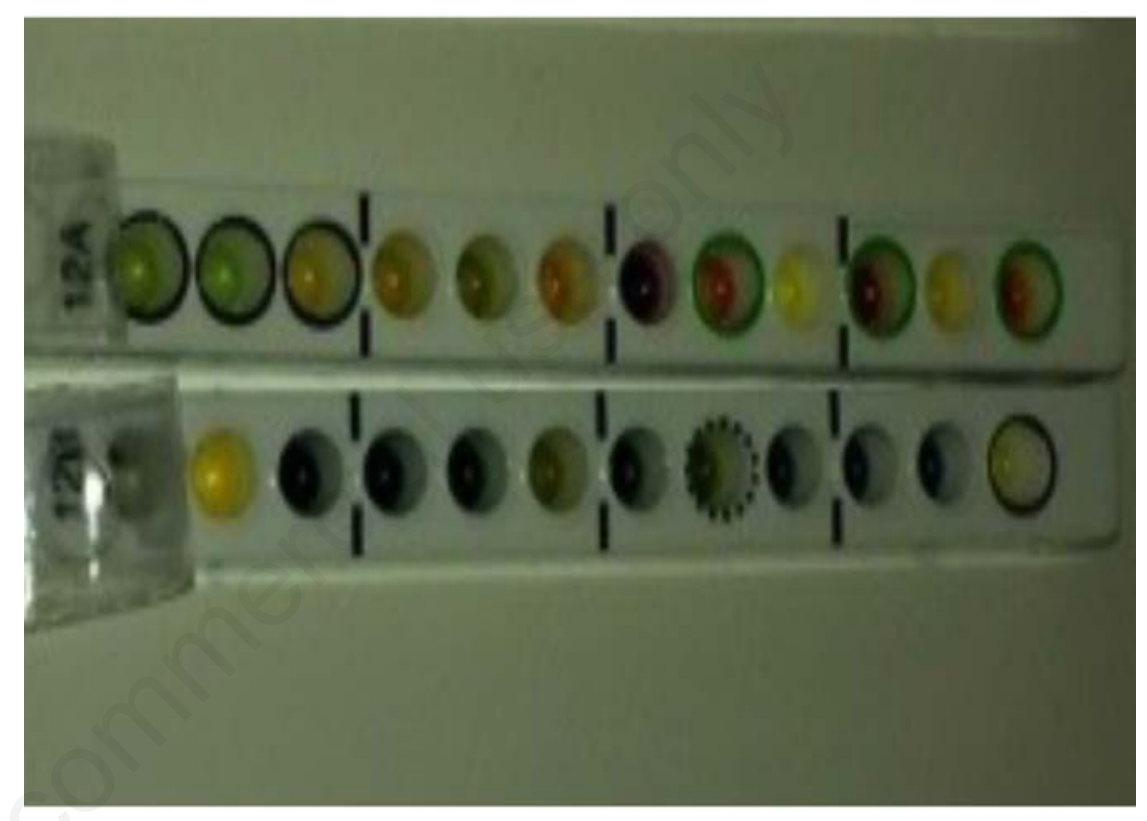

Figure 2. Test of Microbath 24-E system.
Table 3. Protein bands were obtained from both primary and secondary metabolite. The primary metabolite had 11 protein bands more compared with secondary metabolite (Table 3). Their molecular weight were $107.6754 \mathrm{kDa} ; 66.05299 \mathrm{kDa} ; 56.1243$ $\mathrm{kDa} ; 49.6701 \mathrm{kDa} ; 42.2040 \mathrm{kDa} ; 40.5199$ $\mathrm{kDa} ; 38.1189 \mathrm{kDa} ; 35.8607 \mathrm{kDa} ; 34429$ $\mathrm{kDa} ; 23.86 \mathrm{kDa} ; 21554 \mathrm{kDa}$, respectively. Among them are responsible for inhibiting the growth of $S$. aureus. Deduced protein which inhibited $S$. aureus is low molecular proteins. Protein with low molecular weight is usualy responsible for antibacterial actiChellaram et al. (2012) and Laemmli (1970), stated that there are compounds of vity (Sarnthima et al., 2011). Furthermore,

Table 3. Molecular weight compound ( $\mathrm{kDa})$ of primary and secondary metabolites.

\begin{tabular}{lccccc} 
No. & Primary metabolites & Secondary metabolites & No. & Primary metabolites & Secondary metabolites \\
1 & 107.6754 & - & 15 & 45.78512 & 39.70322 \\
2 & 91.49033 & 91.49033 & 16 & 42.20401 & - \\
\hline 3 & 82.63459 & 84.33435 & 17 & 40.5199 & - \\
4 & 79.33714 & 80.96908 & 18 & 38.1189 & - \\
\hline 5 & 76.17127 & 77.73809 & 19 & 35.86017 & - \\
6 & 71.65775 & 73.13173 & 20 & 34.42921 & 32.38911 \\
\hline 7 & 68.79832 & 68.79832 & 21 & 32.38911 & 30.4699 \\
\hline 8 & 66.05299 & - & 22 & 29.85577 & 26.4224 \\
\hline 9 & 63.41721 & 63.41721 & 23 & 26.9659 & 22.91256 \\
\hline 10 & 60.88661 & 59.65943 & 24 & 24.85674 & - \\
11 & 58.45699 & 54.99313 & 25 & 23.86486 & - \\
\hline 13 & 56.12432 & - & 26 & 21.55488 & 19.86895 \\
14 & 49.6701 & - & 27 & 19.86895 & \\
\hline
\end{tabular}




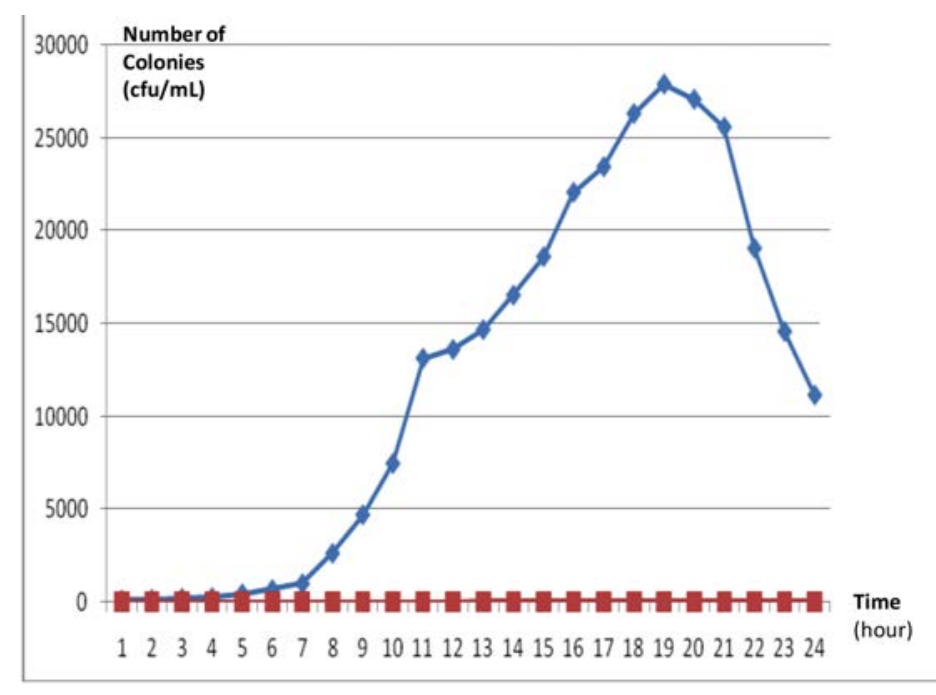

Figure 3. Bacterial growth curve of Vibrio alginolitycus.

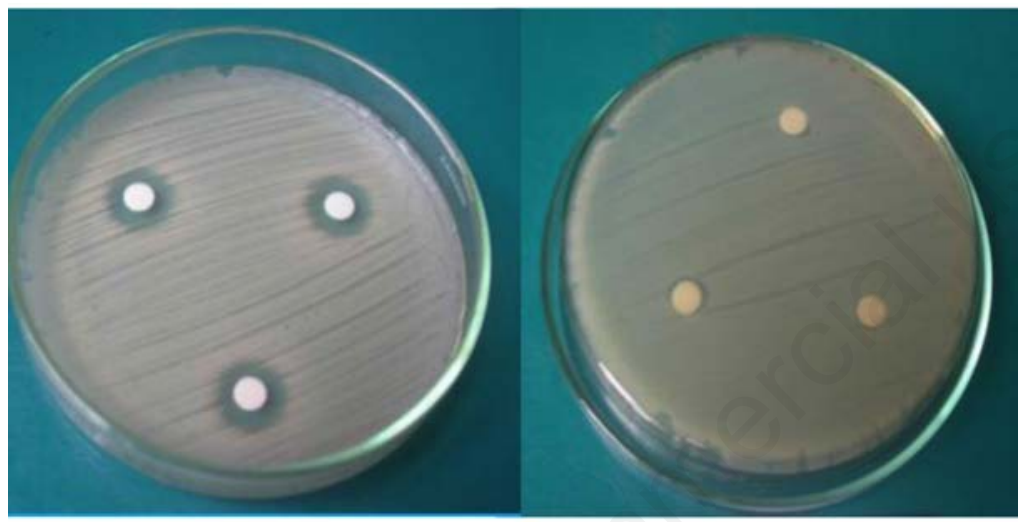

(A)

(B)

Figure 4. Inhibition zone of Vibrio alginolitycus extract against Staphylococcus aureus: A) primary metabolites; and B) secondary metabolites.

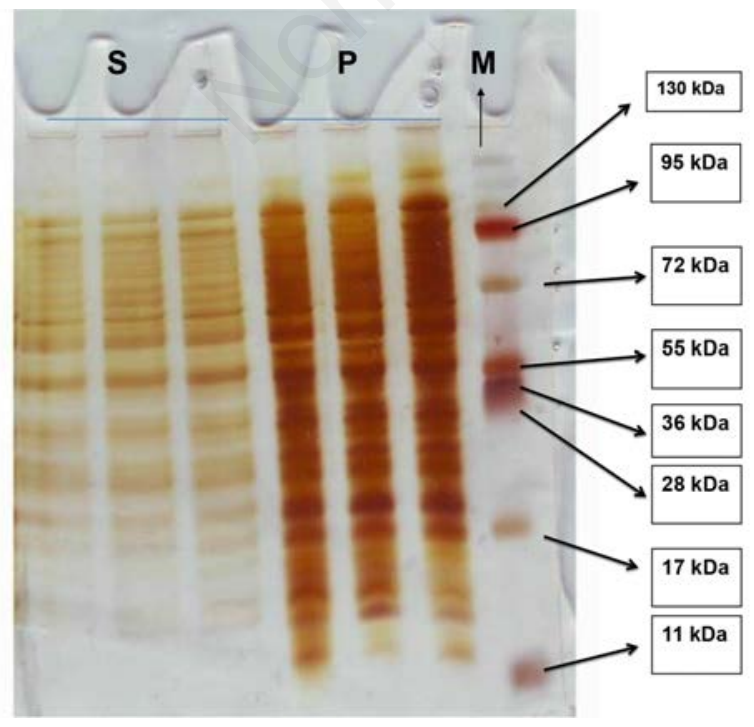

Figure 5. Results of electrophoresis analysis of the primary and secondary metabolites of Vibrio alginolitycus. S, secondary metabolites; P, primary metabolites; M, marker. the class of proteins that can make-bacterial symbiosis with marine invertebrates become antagonistic towards other bacteria. Saranya and Hemashenpagam (2011), also state that microorganisms antagonistic towards other microorganisms are due to produce antibiotics, bacteriocins, siderophores, lysozyme, and protease.

\section{Conclusions}

The primary metabolite of $V$. alginolitycus that was in symbiosis with sponge Haliclona sp. has the ability to inhibit the growth of $S$. aureus. Low molecular weight protein is presumably able to inhibit the growth of $S$. aureus with respect to secondary metabolites. The role of the proteins regarding their inhibiting action towards $S$. aureus needs to be further clarified.

\section{References}

Akindolire MA, Babalola OO, Ateba CN, 2015. Detection of antibiotic resistant Staphylococcus aureus from milk: a public health implication. Int J Environ Res 12:10254-75.

Aydin A, Sudagi M, Muratoglu. 2011. Prevalence of staphylococcal enterotoxins, toxin genes and genetic relatedness of foodborne Staphylococcus aureus strains isolated in the Marmara region of Turkey. Int J Food Microbiol 148:99-106.

Bhimba VC, Beulah, Vinod V, 2013. Efficacy of bioactive compounds extracted from marine sponge haliclona exigua. Asian J Pharm Clin Res 6:34754.

Chellaram C, Anand D, Kesavan M, Chandrika C, Gladis P, 2012. Antagonistic effect of hard coral associated bacteria rom tuticorin coastal waters. Int J Pharm Sci 4:580-3.

Costinar L, Herman V, Pascu C, Marcu A, Marcu A, Faur B, 2010. Isolation and characterization of Vibrio alginoliticus and Pasteurella spp. from siberian sturgeon (Acipenser baerii). Lucrari Sci Med Vet 203:125-7.

Gopi M, Kumaran M, Kumar TTA, Deivasigamani B, Alagappan K, Prasad SG, 2012. Antibacterial potential of sponge endosymbiont marine Enterobacter $\mathrm{sp}$ at Kavaratti Island, Lakshadweep archipelago. Asian Pac J Trop Med 5:142-6.

Hassan MM, Ahaduzzaman M, Alam M, Bari MS, Amin KB, Faruq AA, 2015. 
Antimicrobial resistance pattern against E. coli and Salmonella spp. in environmental effluents. Int J Nat Sci 5:52-8.

Jahan M, Rahman M, Parvej S, Chowdhury SMZ, Haque ME, Talukder MAK, Ahmed S, 2015. Isolation and characterization of Staphylococcus aureus from raw cow milk in Bangladesh. J Adv Vet Anim Res 2:49-55.

Laemmli UK, 1970. Cleavage of structural proteins during the assembly of the head of bacteriophage T4. Nature 227:680-5.

Majali I, Haitham NQ, Syed ZI, Shahbudin S, Deny S, Osama YA, 2015. Potential antimicrobial activity of marine sponge Neopetrosia exigua. J Basic Appl Res $1: 1-13$

Mehbub MF, Lei J, Franco C, Zhang W, 2014. Marine sponge derived natural products between 2001 and 2010: trends and opportunities for discovery of bioactives. Mar Drugs 12:4539-57.

Murniasih T, Rachmawati RS, 1998. Isolation of the antimicrobial bioactive substances of origin sponge from Pari Island, Seribu Islands. The research and development of oceanology. Marine Natural Products Laboratory-LIPI, Jakarta, Indonesia.
Mustapha S, Mustapha EM, Brahim B, Nozha C, 2012. Characterization of Vibrio alginolyticus Trh positive from Mediterranean environment of Tamouda Bay (Morocco). World Environ 2:76-80.

Nursyam H, Andayani S, Salis H, 2013. Antibacterial activities of sponge extracts (Geodia sp.) against Staphylococcus aureus, and Escherichia coli. Global J Med Plant Res 1:88-92.

Nursyam H, Widjanarko SB, 2016. The survival of Pediococcus acidilactici (0110<-TAT-1), Lactobacillus casei (NRRL-B 1922) and Listeria monocytogenes (ATCC 1194) on the Curing Types. South Asian J Exp Biol 6:34-8.

Prihanto AA, Firdaus M, Nurdiani R, 2012. Anti-methicillin resistant Staphylococcus aureus (MRSA) of methanol extract of mangrove plants leaf: preliminary report. Drug Invent Today 4:439-40.

Sabdono A, Radjasa OK, 2006. Anti-bacterial property of a coral-associated bacterium Basillus sp. againts coral pathogenic BBD (Black band disease). J Coast Dev 9:175-82.

Saha B, Bal M, 2013. Emergence of multidrug resistant clinical strains of
Staphylococcus aureus. Int J Nat Sci 3:1-6.

Saranya SN, Hemashenpagam N, 2011. Antagonistic activity and antibiotic sensitivity of lactic acid bacteria from fermented dairy products. Adv Appl Sci Res 2:528-34.

Sarnthima R, Thammasirirak S, Boonchalee P, Khammuang S, 2011. Antibacterial activity of Bauhinia acuminata L. seed protein extract with low hemolytic activity against human erythrocytes. Chiang Mai J Sci 38:242-51.

Sugito HN, Matsuo Y, Hiroshe N, Iwato, Deguchi Y, 1997. Vibrio sp. strain NM 10 withh an inhibitory effect against Pasteurella piscicida from the intestine of Japanese coastal fish. Appl Environ Microbiol 63:4986-9.

Suleria HAR, Osborne S, Masci P, Gobe P, 2015. Marine-based nutraceuticals: an innovative trend in the food and supplement industries. Mar Drugs 13:633651.

Zhang XX, Ma TL, Feng B, Liu Q, Yuan L, Fan C, Huang H, Yang Q, 2015. Biodiversity of the symbiotic bacteria associated with toxic marine Dinoflagellate Alexandrium tamarense. J Biosci Med 3:23-8. 